\title{
Kemampuan Guru Dalam Berkomunikasi Terhadap Peningkatkan Minat Belajar Siswa di SDIT Ummi Darussalam Bandar Setia
}

\author{
Wahyu Iskandar \\ UIN Sunan Kalijaga Yogyakarta \\ wiskandar921@gmail.com
}

\begin{abstract}
Communication is one of the bases to determine teaching success. Teaching success is described from how well teachers can communicates to their students. The aim of this study to investigate: (1) The teachers' ability to communicate towards the improvement of students' learning interest in SD IT Ummi Darussalam Bandar Setia. (2) The supporting and obstacles factors of communication that teachers have in teaching. This research is a type of qualitative study applying direct observation, in-depth interviews and document analysis of data collection. The results of this study prove that teachers' communication in increasing students' learning interest in Elementary School of IT Ummi Darussalam is not good. That happens because there are obstacles that affect miscommunication between them i.e. the teacher has not been able to manage the classroom and master the teaching well by using Bahasa Indonesia in explaining the lesson inside or outside the classroom, so that it affects students' learning interest in Elementary School of IT Ummi Darussalam.
\end{abstract}

Keywords : Teachers' Communication Skills, Interest, Students' Learning

Abstrak: Komunikasi adalah dasar menentukan pola keberhasilan dalam mengajar. Keberhasilan mengajar dilihat dari seberapa baik komunikasi seorang Guru kepada siswanya. Penelitian ini bertujuan untuk mengetahui : (1) Kemampuan Guru dalam berkomunikasi terhadap peningkatan minat belajar siswa di SD IT Ummi Darussalam Bandar Setia. (2) Faktor pendukung dan penghambat apa saja dalam berkomunikasi guru ketika sedang mengajar. Jenis penelitian ini adalah penelitian kualitatif dengan teknik pengumpulan data observasi langsung, wawancara yang mendalam dan studi dokumen. Hasil penelitian ini menunjukkan bahwa kemampuan berkomunikasi guru dalam meningkatkan minat belajar siswa di SD IT Ummi Darussalam Darussalam yang terjadi adalah Komunikasi yang kurang baik antara guru dengan siswa, karena ada hambatan hambatan yang mempengaruhi tidak baiknya antara komunikasi guru dan siswa, yakni guru belum mampu sepenuhnya menguasai kelas dengan cara memberikan pelajaran yang baik dengan bahasa indonesia yang baik dalam menjelaskan didalam kelas maupun diluar kelas, sehingga mempengaruhi terhadap minat belajar siswa di SD IT Ummi Darussalam.

AR-RIAYAH : Jurnal Pendidikan Dasar vol. 3, no. 2, 2019

IAIN Curup - Bengkulu| pISSN2580-362X; eISSN2580-3611

http://journal.iaincurup.ac.id/index.php/JPD 
Kata Kunci: Kemampuan Berkomunikasi Guru, Minat, Belajar siswa PENDAHULUAN

Guru adalah orang yang digugu dan ditiru, etika, ucapan dan tindakannya oleh peserta didik. Karena keberhasilan proses belajar mengajar sangat ditentukan oleh kemampuan guru dalam mengajar. Tugas guru adalah menyampaikan materi pelajaran dengan baik dan mudah dicerna oleh peserta didik melalui komunikasi yang efektif. Komunikasi merupakan dasar eksistensi dalam menentukan pola keberhasilan belajar. Atas dasar komunikasi yang baik akan timbul suasana belajar yang kondusif antara guru dan peserta didik.

Komunikasi merupakan sarana atau media dalam pengoperan rangsangan. Dalam komunikasi guru dan peserta diidik akan saling mempengaruhi, sehingga dengan demikian terbentuklah pengetahuan tentang pengalaman masing masing. Komunikasi dapat membentuk watak peserta didik saling pengertian, menimbulkan rasa kedekatan, memelihara kasih sayang, mempengaruhi sikap yang akhirnya dapat menimbulkan tindakan nyata. Hubungan guru dan peserta didik dapat ditingkatkan dengan memahami dan memperbaiki komunikasi. dimana muaranya peserta didik akan lebih mudah menerima pesan pesan yang disampaikan oleh guru.1

Dalam praktiknya guru memiliki peran penting dalam mewujudkan tujuan pendidikan nasional. Keberhasilan pembelajaran merupakan dambaan dari seorang guru. Pembelajaran dikatakan berhasil apabila tujuan dari suatu pembelajaran dapat tercapai. Namun tidaklah mudah bagi seorang guru untuk mencapai tujuan pembelajaran tanpa diimbangi dengan inovasi-inovasi dalam pembelajaran.

Kemampuan berkomunikasi guru terutama dengan peserta didik yang bertujuan agar pesan yang disampaikan dapat meningkatkan minat anak dalam belajar yakni diperlukan kemampuan berkomunikasi yang baik untuk mengembangkan seluruh potensi yang ada pada anak agar dapat berkembang secara optimal. Komunikasi mensyaratkan bahwa pendidik "sebagai sumber" harus berupaya agar pesan yang diutarakannya benar-benar mengena dan membuat anak tertarik. Ketertarikan inilah yang akan menumbuhkan minat belajar dan mengembangkan potensi pribadinya.

Upaya untuk mencapai interaksi belajar mengajar perlu adanya komunikasi yang baik antara guru (komunikator) dengan siswa (komunikan). Sehingga terpadu dua kegiatan yang berdaya guna dalam mencapai tujuan pengajaran dan pendidikan dimana siswa dapat sukses dalam tugas belajarnya,

1 Sukardjo, Landasan Konsep Pendidikan \& Aplikasinya (Jakarta: Rajawali Pers, 2010). Hal. 14 
Maka guru dapat berhasil mengajar dan mendidik sesuai dengan tujuan yang hendak dicapai. Pada dasarnya minat belajar siswa sangat dipengaruhi adanya komunikasi guru. Seorang guru yang jarang melakukan komunikasi dengan muridnya akan atau bisa mengalami kegagalan dalam proses belajar mengajar.

Tetapi yang terjadi di kelas IV SD IT Ummi Darussalam adalah seorang guru kurang mampu menangani siswa yang kesulitan dalam belajar. juga sulit dalam mempertahankan tingkah laku siswa yang baik karena kurangnya keterampilan berkomunikasi dan interaksi antara guru dengan siswa, sehingga pembelajaran yang efektif tidak tercapai dalam proses belajar mengajar. Dalam hal ini siswa tidak mampu mengikuti pembelajaran dengan baik dan bersemangat dalam meraih prestasi. 2

\section{Pengertian Komunikasi}

Konsep dalam berkomunikasi paling tidak ada dua hal makna penting didalamnya. Pertama, komunikasi adalah suatu proses, yakni aktivitas untuk mencapi tujuan komunikasi itu sendiri. Dengan demikian proses komunikasi terjadi bukan secara kebetulan, akan tetapi dirancang dan diarahkan kepada pencapai tujuan. Kedua, dalam proses komunikasi selamanya melibatkan komponen penting yakni sumber pesan, yaitu orang yang menyampaikan atau mengomunikasikan sesuatu, pesan itu sendiri atau segala sesuatu yang ingin disampaikan atau materi komunikasi atau penerima pesan, yaitu orang yang akan menerima informasi.3

Komunikasi menurut (Onong 2003) secara etimologi berasal dari bahasa latin "Communicatio" istilah ini bersumber dari dari perkataan "communis" yang berarti sama, sama disini maksudnya sama makna atau arti. Komunikasi secara umum mempunyai arti hubungan antara individu berdasarkan unsur-unsur yang terkandung didalamnya, kegiatan komunikasi memiliki dua makna. Pertama ide komunikasi sebagai dasar yang hakiki bagi hubungan manusia. Kedua komunikasi sebagai proses yang menyebabkan hubungan tersebut menjadi suatu kegiatan. Melalui dua makna tersebut menyebabkan banyak ahli memberikan pengertian komunikasi yang berbeda-beda sesuai dengan sudut pandang keahlian mereka.4

Istilah komunikasi menurut Anton M. Moeliono adalah pengirim dan penerima pesan atau berita antara dua orang atau lebih dengan cara yang tepat

\section{Ibid Hal.10}

3 Wina Sanjaya, Media Komunikasi Pembelajaran (Jakarta: Kencana, 2012). Hal.

10

4 Mohamad Syarif Sumantri, Strategi Pembelajaran (jakarta: Raja Grafindo

Persada, 2016).hal. 350 
sehingga pesan yang dimaksud dapat dipahami.5 Komunikasi adalah suatu proses penyampaian pesan itu memperoleh pemahaman sama seperti yang menyampaikan pesan dengan suatu tujuan tertentu.6 Pesan itu dapat berupa konsep, makna atau pendapat yang disampaikan.

Komunikasi pun berlangsung dalam proses dan kegiatan pembelajran. Tidak bisa terbayangkan bagaimana jadinya proses pembelajaran bila tidak terjadi komunikasi, karenanya komunikasi adalah jantung dari proses pembelajaran. Guru menjelaskan materi pembelajaran di kelas, siswa berdiskusi, mahasiswa menulis makalah atau guru dan siswa sama sama membahas sebuah topik diskusi, semuanya merupakan bentuk dan kegiatan komunikasi yang berlangsung dalam pembelajaran. Apa yang dikomunikasikan dan bagaimana mengkomunikasikannya merupakan hal penting dalam komunikasi pembelajaran dimana pun, baik pada pendidiakn formal, nonformal maupun informal.

Dari beberapa pengertian oleh para ahli dapat disimpulkan bahwa komunikasi merupakan kegiatan atau proses penyaluran informasi, perasaan, ide, yang disampaikan kepada orang lain (komunikan). Atau dengan kata lain komunikan merupakan gejala yaitu pernyataan yang dilakukan oleh manusia (individu), pernyataan tersebut dapat dilakukan dengan bahasa lisan, tulisan atau isyarat -isyarat atau simbol-simbol.

\section{Tujuan komunikasi}

Komunikasi merupakan proses yang memungkinkan satu sama lain saling mempengaruhi dan memahami, selanjutnya adalah memindahkan atau mengirim informasi dan pengertian dengan menggunakan simbol verbal dan non verbal. Pada dasarnya komunikasi bertujuan untuk memberikan informasi, mendidik dan menerangkan informasi bahkan menghibur komunikan. agar komunikan terpengaruh dan berubah sifat sesuai dengan kehendak komunikator dan untuk mempengaruhi tingkah laku si penerima informasi yang dinyatakan dalam tindakan-tindakan tertentu sebagai respons terhadap informasi yang diterimanya. 7

Umumnya dalam tataran sosial tentu manusia membutuhkan interaksi dengan manusia lain dan alam disekitarnya "interaksi sosial" untuk mendukung kelangsungan hidupnya. Dalam berinteraksi itulah dibutuhkan komunikasi baik

\footnotetext{
5 Anton M. Moeliono, Kamus Besar Bahasa Indonesia (Jakarta: Balai Pustaka, 2008). Hal. 860

6 Zakiyah Daradjat, Metode Pengajaran Agama Islam (Jakarta: Bumi Aksara, 2000). Hal. 111

7 Syafaruddin Dkk, Administrasi Pendidikan (Medan: Perdana Publishing, 2016). Hlm 66
} 
dalam bahasa verbal "bahasa lisan/tulisan" maupun bahasa isyarat "bahasa tubuh atau simbol". Komunikasi dibutuhkan untuk saling mengenal, menyampaikan pesan,saling bekerja sama, berbuat kebajikan dll, baik untuk tujuan-tujuan kemasyarakatan, keagamaan maupun tujuan individual.

Dengan demikian tujuan komunikasi sebenarnya adalah untuk mencapai pengertian bersama, sesudah itu mencapai persetujuan mengenai suatu pokok ataupun masalah yang merupakan kepentingan bersama. Dengan kondisi yang demikian akan terjalin hubungan yang harmonis dan saling mengerti satu sama lain dalam rangka mencapai tujuan yang telah ditetapkan bersama. Dalam Islam komunikasi juga bisa dijadikan media untuk ibadah yaitu dengan cara berlaku baik atau berbuat kebajikan kepada sesama manusia, alam maupun Tuhan.

\section{Proses Komunikasi}

Pada hakikatnya kegiatan belajar mengajar adalah suatu proses komunikasi. Proses komunikasi (proses penyampaian pesan) harus diciptakan, diwujudkan melalui kegiatan penyampaian dan tukar menukar pesan atau informasi oleh setiap guru dan peserta didik. Hal ini yang dimaskud pesan atau informasi dapat berupa pengetahuan, keahlian, ide dan pengalaman. Dalam proses komunikasi terdapat lima unsur penting yang arus diperhatikan, yaitu:

a. Sender, yaitu pihak yang mengirim pesan atau berita disebut juga komunikator.

b. Message adalah pesan atau infomasi yang hendak disampaikan kepada pihak lain.

c. Medium adalah sarana penyaluran pesan-pesan (media)

d. Receive, adalah pihak penerima pesan atau informasi. Disebut juga komunikan.

e. Response adalah tanggapan atau reaksi komunikan terhadap pesan atau informasi yang diterima dari pihak komunikator. 8

\section{Faktor Pendukung Komunikasi}

Pengajaran pada dasarnya merupakan suatu proses terjadinya interaksi antara guru dengan siswa melalui kegiatan terpadu dari dua bentuk kegiatan, yakni kegiatan belajar siswa dengan kegiatan mengajar guru. Belajar pada hakikatnya adalah proses perubahan tingkah laku yang disadari. Mengajar pada hakikatnya adalah usaha yang direncanakan melalui pengaturan dan penyediaan kondisi yang memungkinkan siswa melakukan berbagai kegiatan belajar sebaik mungkin. 
Komunikasi yang tidak hanya melibatkan interaksi dinamis antar guru dengan siswa tetapi juga melibatkan interaksi dinamis antara siswa yang satu dengan siswa yang lainnya. Misalnya guru mengadakan diskusi dalam kelas.Dengan adanya tiga pola komunikasi yang jelas dari komunikator kepada komunikan diharapkan dapat memperlancar proses kegiatan belajar mengajar secara efektif dan efisien.9

\section{Faktor hambatan Komunikasi}

Komunikasi yang dilakukan seseorang dengan orang lain atau banyak orang yang pada awalnya dimaksudkan untuk mencapai tujuan tertentu bisa jadi tidak akan menghasilkan sesuatu yang efektif. Sumber di sini maksudnya adalah pihak penggagas, komunikator dan jugatermasuk pengajar, yang dimaksud dengan komunikator ialah orang yang menjadi penggagas atau ide yang disampaikan kepada orang lain. Hambatan komunikasipada komunikator ini disebabkanbeberapa hal:

a. Bahasa.

Penggunaan bahasa yang tidak sesuai dengan kondisi sasaran, misalnya bertele-tele dan tekanan suara yang lemah, bisa menghambat penerimaan informasi oleh sasaran. Penyebabnya bisa bermacam-macam, misalnya: penggunaan kata yang salah penyusunan kalimat yang keliru sehingga menimbulkan salah pengertian.

b. Keahlian

Komunikator yang mempunyai keahlian kurang bisa menyebabkan kesalahpahaman dalam penyampaian komunikasi.10

\section{Sifat sifat Minat}

Minat berhubungan dengan sesuatu yang menguntungkan dan dapat dapat menimbulkan kepuasan bagi dirinya. Kesenangan merupakan minat yang sifatnya sementara. Semakin sering minat diekspresikan dalam kegiatan akan semakin kuat minat tersebut, sebaliknya minat akan semakin pupus apabila tidak ada kesempatan untuk mengekspresikannya.11

Menurut Hurlock, (1999) minat merupakan suber motivasi yang mendorong orang untuk melakukan apa yang mereka inginkan bila mereka bebas memilih. Menurut crow and crow (1984) minat dapat menunjukkan 2002). Hlm 6

9 Asnawi dan Basyiruddin Usman, Media Pembelajaran (Jakarta: Ciputat press,

10 Nardianto Elvinaro Dkk, Filsafat Ilmu Komunikasi (Simbiosa Rekatama Media, 2007). Hlm. 98

11 Yudrik Jahja, Psikologi Perkembangan (Jakarta: kencana, 2011). hlm 63 
kemampuan untuk memperhatikan seseorang, sesuatu barang atau kegiatan, atau sesuatu yang berpengaruh bagi dirinya sendiri. Dengan kata lain, minat dapat menjadi sesuatu kegiatandan hasil dari turut sertanya dalam kegiatan itu.12

Minat memiliki sifat dan karakter khusus, sebagai berikut.

a. Minat bersifat Pribadi (Individual), ada perbedaan antara minat seseorang dan orang lain

b. Minat menimbulkan efek diskriminatif.

c. Erat hubungannya dengan motivasi, mempengaruhi, dan dipengaruhi motivasi.

d. Minat merupakan sesuatu yang dipelajari, bukan bawaan lahir dan dapat berubah tergantung pada kebutuhan, pengalaman dan metode.13

\section{Metode Penelitian}

Penelitian ini menggunakan penelitian kualitatif. Dalam bentuknya penelitian ini untuk mendeskripsikan dan menganalisis fenomena, peristiwa, aktivitas sosial, kepercayaan, dan pemikiran seseorang secara individual maupun kelompok. Jenis penelitian ini adalah penelitian studi kasus dengan teknik pengumplan data digunakan meliputi observasi, wawancara dan dokumentasi. Penelitian ini bertujuan mendeskripsikan pemahaman guru wali kelas terhadap perkembangan peserta didik di SD IT Ummi Darussalam Bandar Setia Kec. Percut sei tuan. Dengan peninjauan dari empat ranah perkembangan peserta didik meliputi: 1) perkembangan fisik, 2) perkembangan Intelektual, 3) perkembangan emosi, 4) perkembangan sosial dan moral.

\section{HASIL DAN PEMBAHASAN}

\section{Temuan Umum}

SD IT Ummi Darussalam pertama kali dibuka pada tahun 2006 membuka 4 kelas rombongan belajar. Terdiri dari dari kelas 1, pindahan kelas 2, pindahan kelas 3 dan pindahan kelas 4 . Selama perjalanan panjangnya, pada tahap awal dibuka keinginan masyarakat begitu besar untuk menyekolahkan anaknya di SD IT Ummi Darussalam. SDIT Ummi Darussalam hanya membangun 2 ruang kelas untuk kelas 1 dan kelas 2, kemudian 1 ruang guru dan kepala sekolah, 2 kamar mandi dan 1 gudang.

12 Makmun Khairani, Psikologi Belajar (Yogyakarta: Aswaja Presindo, 2013).

HIm. 136-137

13 Opcit, hal. 63-64 
Sarana yang seba terbatas tidak mampu menampung animo masyarakat yang begitu besar. Awalnya hanya membuka kelas 1 dan kelas 2, akhirnya ditambah dengan menerima siswa pindahan pada kelas 3 dan kelas 4 .

Kondisi bangunan yang belum siap untuk kelas 3 dan kelas 4, akhirnya menempatkan siswa kelas 3 dan kelas 4 pada kelas sayap kanan dan kiri masjid, yang seyogyanya dipakai untuk kegiatan belajar baca qur'an masyarakat sekitar. Daya tampung ruangan tersebut tidak memadai untuk menampung jumlah siswa yang ada, sehingga pembelajaran kurang nyaman.

Melihat kondisi yang kurang nyaman, 6 bulan kemudian orang tua murid yang diprakarsai Persatuan Orang Tua Murid dan Guru (POMG) secara swadaya memberikan bantuan untuk pembangunan kelas 3 dan kelas 4 . Bantuan berupa dana, material, dan memasukkan proposal pada instansiinstansi yang perhatian terhadap pendidikan. Selanjutnya proses pengembangan SDIT Ummi Darussalam berjalan sampai saat ini melalui dana pembangunan dari orang tua.

VISI dan MISI SD IT Ummi Darussalam

Visi dari SD IT Ummi Darussalam adalah:

"Terwujudnya anak yang sehat, cerdas, ceria berakhlak mulia serta beragama."

MISI

Adapun misi dari SD IT Ummi Darussalam adalah sebagai berikut:

a. Mengupayakan pemerataan layanan pendidiakn terhadap seluruh anak didik.

b. Menumbuhkembangkan kecerdasan anak didik .

c. Membentuk pribadi anak didik agar menjadi anak sholeh dan soleha.

d. Membimbing dan mengarahkan potensi anak didik supaya menjadi anak anak unggul dan pemberani

e. Mengenalkan anak didik pada cinta, baik cinta pada Allah, Rasulullah, orang tua, diri sendiri dan lingkungan

f. Membuka kreativitas dan imajinasi anak didik

g. Membangun kepercayaan diri pada setiap anak didik

Tabel : Keadaan Guru dan Karyawan SDIT Ummi Darussalam

\begin{tabular}{llc} 
No & $\begin{array}{l}\text { Tingkat } \\
\text { Guru dan Karyawan }\end{array}$ & Jumlah \\
\hline 1 & S2 & 0 \\
\hline 2 & S1 & 8 \\
\hline
\end{tabular}




\begin{tabular}{clc}
\hline 3 & D3 & 2 \\
\hline 4 & D2 & 0 \\
\hline 5 & D1 & 0 \\
\hline 6 & SMA & 2 \\
\hline & Jumlah & 12
\end{tabular}

Sumber: Profil SDIT Ummi Darussalam Pelajaran 2018-2019

Berdasarkan table 2 dapat dilihat bahwa secara umum guru dan karyawan memiliki pendidikan S1, sedangkan guru yang berpendidikan D3 sebagian sedang menempuh pendidikan S1. Karyawan yang memiliki pendidikan SMA adalah cleaning service dan karyawan perpustakaan.

Pembinaan dan peningkatan kualifikasi guru-guru terus dilakukan dengan pelatihan-pelatihan, workshop, dan studi banding ke sekolah-sekolah yang memiliki karakteristik yang sama. Adapun program kegiatan untuk pengembangan SDM adalah:

1. Pelatihan dan workshop internal

2. Pelatihan dan workshop eksternal

3. Studi banding

4. Kajian keislaman

5. Kelas tahsin-tahfidz Al-qur'an

6. KKG

7. Kelas psikologi anak

8. Kelas Bahasa Inggris

\section{Temuan Khusus}

Adapun kemampuan berkomunikasi guru dalam meningkatkan minat belajar siswa di SD IT Ummi Darussalam Bandar Setia sebagai berikut :

Berdasarkan hasil penelitian masih banyak lemahnya kemampuan guru dalam berbahasa Indonesia secara baik dan benar dan kecakapan yang efektif menyebabkan siswa menjadi sulit menggunakan bahasa Indonesia yang baik dan benar, dan siswa sulit juga untuk memahami pembelajaran yang diberikan oleh guru di SD IT Ummi Darussalam, hal ini karena mereka terbiasa menggunakan bahasa yang tidak baku dan bahasa daerah contoh kecilnya yang ditemukan seperti "anak anak Ibuk, cak dengerkan Ibuk, sekarang kita belajar bahasa Indonesia ya" yang seharusnya " anak anak Ibu coba perhatikan Ibu, sekarang kita akan belajar Babasa Indonesia", kemudian ketika guru tersebut memarahi siswanya dia mengatakan "bey anak anak, kalok kelen masih ribot, ibuk cubit nanti kelen semua. Mau.. ?' yang seharusnya kalimatnya "anak anak ibu jangan ribut ya ,nanti kalau mau bermain, cerita cerita diwaktu istirahat saja ya. Hal ini sangat berpengaruh dalam terjadinya komunikasi saat pembelajaran. terbukti terkadang jika siswa tidak berani mengutarakan pendapatnya terkadang terdiam karena sulit memahami 
bahasa yang sederhana untuk mengungkapkan dalam bahasa Indonesia yang baik dan benar.

Hasil wawancara bersama guru 1 tentang melaksanakan pengajaran dengan kemampuan komunikasi yang baik, maka mereka guru menjelaskan sebagai berikut :

"Sebelum saya mengajar terkadang saya tidak efektif untuk menyiapkan semua keperluan siswa yang akan di ajarkan termasuk materi, ya karena mungkin dalam pengajaran saya karena banyak kesibukan saya di luar, sehingga banyak siswa yang sulit memahami pelajaran dengan baik".14

Dari hasil wawancara diatas, maka disimpulkan bahwa hasil jawaban guru sebagai informasi kunci berkesinambungan dengan hasil jawaban kepala SD IT Ummi Darussalam.

Kemudian kesiapan mental dalam mengajar adalah hal yang harus di utamakan karena berdampak bagi tinggi atau rendahnya minat belajar siswa, maka Hal yang demikian ditanyakan oleh peneliti kepada kepala sekolah SD IT Ummi Darussalam beliau menjelaskan.

"Terkadang ada guru yang mengajar kurang bersemangat dan mentalnya banyak memiliki masalah, jika ada persiapan pembelajaran yang belum dikerjakan bisa menjadi sebab mengapa peserta didik terkadang sulit memahami apa yang dijelaskan oleh guru, itulah sebabnya kesiapan mental guru dalam mengajar sangat perlu".15

Dari hasil wawancara diatas dapat disimpulkan bahwa persiapan mental adalah persiapan penting yang harus dilakukan oleh seorang guru, karena dengan persiapan mental yang baik guru akan mampu menguasai kelas dengan efektif dan siswa pun tumbuh minatnya dalam pembelajaran. Maka kemampuan berkomunikasi guru dalam meningkatkan minat belajar siswa pada kegiatan belajar mengajar, belum sempurna menciptakan iklim komunikatif dalam kegiatan belajar mengajar. artinya komunikasi yang di terapkan guru kepada siswa hanya sebatas komunikasi dari pengirim kepada penerima pesan. Seharusnya guru mampu membuat rangsangan terjalinnya komunikasi timbal balik antara guru ke siswa, siswa ke guru dengan kecakapan atau komunikasi yang baik sesuai bahasa Indonesia yang baik. Faktor pendukung kemampuan berkomunikasi guru sebagai berikut:

14 Wawancara dengan guru 1, selasa, 20 maret 2018 15 Wawancara dengan Kepala Sekolah SD IT Ummi Darussalam, selasa, 20 maret 


\section{Faktor lingkungan belajar}

Selain itu faktor pendukung terjadinya komunikasi disebabkan oleh baiknya ekologis atau lingkungan belajar yang baik, hal ini sangat berpengaruh terhadap efektifnya sebuah pembelajaran dan menumbuhkembangkan minat belajar yang ada pada seorang siswa.

\section{Faktor Psikologi}

Faktor pendukung kemampuan berkomunikasi guru yang lainya adalah seorang guru harus mampu memperhatikan faktor pendukung psikologis yang ada pada dirinya sebagai komunikator dan mampu melihat faktor psikologis seorang murid sebagai komunikan, karena pada umumnya guru atau komunikator ketika menyampaikan materi pembelajaran dengan baik dilandasi dengan psikologi yang baik, begitu juga sebaliknya. Namun sejauh peneliti saat mewawancarai kehidupan eksternal guru tersebut. tidak ada yang bermasalah dengan kehidupan di luar sekolah. Baik itu terkait keluarga kerabat dan lainnya sehingga psikologi pada guru tersebut tidak meiliki gangguan.

\section{Faktor Komunikasi}

Komunikasi yang baik yang diberikan guru kepada siswa juga berpengaruh besar terhadap kemampuan siswa dan minat belajar siswa saat menerima materi pembelajaran, bagi siswa yang merasa pintar guru lebih mudah memberikan motivasi dan juga berkomunikasi dengan siswa yang pintar, dan sebaliknya bagi siswa yang merasa kurang pintar terkadang mereka merasa minder saat melihat teman-temannya lebih pintar darinya malah bukan termotivasi untuk meningkatkan kemampuan belajarnya. Pada wawancara yang dilakukan oleh peneliti kepada kepala sekolah SD IT Ummi Darussalam terkait faktor pendukung kemampuan komunikasi guru beliau mengatakan :

"Seharusnya dalam komunikasi yang baik antara guru dan siswa seharusnya guru harus mampu untuk menguasai kelas dan berbuat adil dengan cara memberikan motivasi kepada siswa yang pintar dan juga yang kurang pintar, agar seluruh siswa merasa diperhatikan oleh guru".16

Perihal wawancara diatas guru seharusnya jangan hanya memberikan motivasi kepada yang pintar saja, Dalam hal ini guru sebaiknya mampu memperhatikan faktor pendukung komunikasi kepada siswa dalam pembelajaran agar sasaran pembelajaran akan tercapai dengan baik, salah satunya adalah media pembelajaran yang menjadi salah satu faktor pendukung

16 Wawancara dengan Kepala Sekolah SD IT Ummi Darussalam, jumat, 02 April 
kemampuan berkomunikasi guru dalam menyampaikan pembelajaran, agar minat belajar siswa tumbuh dalam semangat belajar yang ada pada diri seorang siswa.

Selain itu yang menjadi faktor pendukung kemampuan berkomunikasi guru pada semua tingkat pendidikan dituntut untuk memberikan perhatian khusus kepada beberapa orang siswa. Dengan media pembelajaran tertentu, guru dapat melakukan kegiatan dengan mengindividualisasikan pengajaran, misalnya penggunaan model, gambar sebagai tindakan yang pertama, kemudian dengan menggunakan media pembelajaran yang lebih modern, misalnya tape recorder, slide, dan yang lainnya. Faktor Penghambat berkomunikasi guru sebagai berikut :

\section{Faktor bahasa}

Masih lemahnya kemampuan guru dalam berbahasa Indonesia secara baik dan benar, karena dalam pembelajaran berlangsung guru masih sering menggunakan bahasa yang tidak baku yang menyebabkan sulitnya dilakukan oleh siswa SD IT Ummi Darussalam untuk berkomunikasi yang baik dan benar, hal ini sangat berpengaruh terhadap minat belajar siswa dan terjadinya komunikasi yang tidak efektif, bisa saat pembelajaran terbukti terkadang jika siswa belum berani mengutarakan pendapatnya terkadang terdiam karena tidak bisa mengungkapkan dalam bahasa Indonesia yang baik dan benar. Kesiapan mental anak sangat bergantung pada pertumbuhan dan kematangan otak dan berpengaruh besar pada kemampuan bahasa anak.

Hal yang siswa di SD IT Ummi Darussalam adalah siswa tidak terbiasa dalam menggunakan bahasa Indonesia yang baik dan benar dalam komunikasi karena disebabkan guru memberikan pengajaran yang tidak efektif dalam berbahasa yang baik dan benar sehingga ketika siswa masuk dalam lingkungan yang mengharuskan untuk menggunakan bahasa Indonesia yang baik dan benar siswa merasa minder sehingga tidak terjadi komunikasi yang baik ketika proses belajar dikelas.

\section{Faktor Kesiapan}

Kesiapan dalam mengajar adalah hal yang sangat vital bagi seorang guru ketika hendak mengajar. Adapun faktor kesiapan terkait yang terjadi pada guru yang diteliti yakni dari hasil wawancara guru 2 tentang yang menghambat komunikasi, maka mereka menjelaskan sebagai berikut :

"Kami mengetahui seharusnya seorang guru wajib untuk menyiapkan seluruh keperluan pembelajaran, mulai dari penguasaan kelas, media dan materi yang akan disampaikan. Namun karena rata-rata guru disini ada kesibukan lain di luar 
seperti mengajar di sekolah lain, berniaga sehingga memakan waktu untuk menyiapkan itu semua, itulah mengapa mungkin sebahagian guru disini kurang kesiapan mental dalam memberikan pelajaran dan tidak efektif untuk menjelaskan pelajaran dengan bahasa Indonesia yang baik dan benar, maka dampaknya siswa terkadang sulit untuk memahami pelajaran yang ada".17

Ketika dilakukan wawancara bersama kepala sekolah SD IT Ummi Darussalam terkait faktor penghambat komunikasi guru beliau mengatakan sebagai berikut :

"Harapan saya sebenarnya semua guru di SD IT Ummi Darussalam mampu mengemban menjadi guru yang profesional, dan sudah saya ingatkan beberapa kali agar guru efektif dalam mengajar, namun disamping itu saya tidak bisa memaksakan itu semua, karena ada beberapa guru disini yang bukan hanya mengajar disini tetapi ada mengajar di tempat lain dan ada juga yang belum tamat strata 1, maka wajar ketika dalam banyak kesibukan di luar dan belum ada pengalaman mengajar guru tidak mampu menyiapkan secara detail materi ajar, maka pengajaran tidak efektif dan mungkin sebahagian siswa sulit memahami apa yang disampaikan oleh gurunya”.18

Dari wawancara diatas bahwa hasil jawaban guru juga berkesinambungan atas hambatan kemampuan berkomunikasi guru dalam mengajar, tetapi harapan peneliti guru memang harus mampu menjadi guru yang profesional dalam memberikan pelajaran, agar komunikasi yang baik dalam menjelaskan pengajaran akan tercapai.

\section{Faktor Penguasaan kelas}

Terlihat bahwa didalam penguasaan kelas guru belum mampu untuk sepenuhnya percaya diri dalam mengajar. Menjadikan anak siswa sebagai penerima pesan yang baik. Sehingga sulit ditemukan respon positif atau umpan balik dari siswa itu sendiri. Dalam hal ini sedikit sebuah solusi dalam membantu mengatasi kemampuan intelektual pada siswa, antara lain adalah Pengajar atau guru hendaknya juga turut memperhatikan kondisi dan perkembangan kesehatan fisik dan mental siswa, membantu pengembangan sifat-sifat positif pada diri siswa seperti rasa percaya diri dan saling menghormati, memperbaiki kondisi dan terus menerus memberikan motivasi pada siswa, menciptakan

17 Wawancara dengan guru 2, jumat, 23 maret 2019

18 Wawancara dengan Kepala Sekolah SD IT Ummi Darussalam, jumat, 23 maret 
kesempatan belajar yang lebih baik bagi siswa,memberikan rangsangan belajar sebanyak mungkin Guru juga hendaknya dapat memilih dan menerapkan saran dan solusi sesuai dengan kebutuhan dan keperluan.

\section{Faktor Media}

Media pengajaran berfungsi untuk menyampaikan informasi dan mempermudah dalam pencapaian tujuan pembelajaran tetapi tidak semua media dapat dengan mudah digunakan oleh guru dalam proses belajar mengajar, media dalam hal ini berarti alat untuk menyampaikan pesan yang pertama banyak berkaitan dengan masalah-masalah fisik dengan segala jenis kebutuhan biologis seperti kondisi indra, lapar, kurang istirahat, dan haus. Namun dalam hal ini guru dan pihak sekolah juga belum sepenuhnya untuk memprioritaskan media dan lainnya untuk mendukung perkembangan peserta didik.

\section{KESIMPULAN}

Komunikasi guru dengan siswa di SD IT Ummi Darussalam yang terjadi adalah Komunikasi yang kurang baik antara guru dengan siswa, karena ada hambatan hambatan yang mempengaruhi tidak baiknya antara komunikasi guru dan siswa, yakni guru belum mampu sepenuhnya menguasai kelas dengan cara memberikan pelajaran yang baik dengan bahasa indonesia yang baik dalam menjelaskan didalam kelas maupun diluar kelas, yang pada akhirnya sangat berpengaruh terhadap minat belajar siswa. Faktor pendukung kemampuan berkomunikasi guru yakni disebabkan adanya lingkungan belajar yang baik dengan dibangunnya teras belajar oleh pihak sekolah sehingga siswa lebih mudah belajar saat diluar kelas. Ssedangkan faktor penghambat peran komunikasi guru dengan siswa dalam meningkatkan minat belajar siswa di SD IT Ummi darussalam masih lemahnya kemampuan guru dalam menjelaskan dengan bahasa indonesia yang baik dan benar berpengaruh dalam terjadinya komunikasi yang aktif saat pembelajaran dan guru belum mampu memberikan motivasi menyeluruh bagi siswa. ditambah lagi hambatan intelektual siswa karena media yang kurang memadai di dalam sekolah keterbukti terkadang jika siswa sudah berani mengutarakan pendapatnya terkadang terdiam karena tidak bisa mengungkapkan dalam bahasa Indonesia yang baik dan benar.

\section{DAFTAR PUSTAKA}

Asnawi dkk, Media Pembelajaran,Ciputat press, Jakarta, 2006

Elvinaro Ardianto dkk, Filsafat Ilmu Komunikasi, Simbiosa Rekatama Media, Bandung, 2007

Makmun Khairani, Psikologi Belajar, Aswaja Presindo, Yogyakarta, 2013 
Moeliono Anton M., Kamus Besar Bahasa Indonesia, Jakarta : Balai Pustaka 2008.

Syarif Mohamad Sumantri, Strategi Pembelajaran, Raja Grafindo Persada, Jakarta, 2016

Syafaruddin dkk, Administrasi pendidikan, Perdana Publishing, Medan, 2016

Sukardjo, Landasan Pendidikan Konsep \& Aplikasinya, Jakarta: Rajawali Pers, 2010

Wina, Strategi Pembelajaran Berorientasi Standar Proses Pendidikan. Jakarta Keusuma,2007

Yudrik jahja, Psikologi Perkembangan, Jakarta : Kencana, 2011.

Zakiyah Daradjat, Metode Pengajaran Agama Islam, Bumi Aksara, Jakarta, 2000 
